\title{
ВИСТУПИ ПАРЛАМЕНТАРІВ У ФОКУСІ ОНОМАСТИКИ
}

\section{Насакіна С. B.}

\section{ВСТУП}

У сучасному світі протягом останніх десятиліть зростає ступінь зацікавленості науковців у дослідженні політичних текстів, уже сформована політична лінгвістика, одним з об'єктів якої є ресурси мови в боротьбі за політичну владу, а також у процесі політичної конкуренції. Одними 3 перших, хто усвідомив релятивізм істини та брехні в ораторському мистецтві, були Горгій та Протогор, відомі як софісти, давньогрецькі філософи Аристотель та Платон, давньоримський оратор Цицерон. Ідеї античних філософів отримали розвиток у епоху Просвітництва та Новому часі.

Ефективність політичної промови залежить від багатьох факторів, а саме від логіки викладу, риторичних прийомів, жанрової специфіки, актуальності вибраної теми. Здійснювати вплив ораторам у політиці допомагають виражальні засоби мови, а слова в політичному тексті це складні елементи, дослідження яких потребує залучення напрацювань зі сфери риторики й лінгвістики. Особливе значення в структурі політичної промови мають власні назви, які, крім номінативної, виконують інформативну, ідеологічну, культурноісторичну, експресивну, текстотвірну функції. Власні назви є об'єктом дослідження у ономастиці, соціології, археології, культурології, історії, філософії мови. 3-поміж цих дисциплін провідне місце посідає ономастика - «розділ мовознавства, який вивчає власні назви в різних аспектах» ${ }^{1}$. На сучасному етапі $\epsilon$ такі розділи ономастики, як діалектна, когнітивна, літературна, прикладна, теоретична, соціо-ономастика. Прикладна ономастика та соціо-ономастика зумовили розвиток політичної ономастики, яка вивчає власні назви як інструмент політичної комунікації.

Об'єктом дослідження нашої розвідки є політичні промови членів Парламенту Сполученого Королівства Великобританії та Північної Ірландії, Конгресу США, Парламенту Республіки Польща (Національні Збори Польщі) та Верховної Ради України за 2019-2020 роки, які пов'язані з темами «Здоров'я», «Державна мова», «Освіта». Предметом

1 Бучко Д.Г., Ткачова Н.В. Словник української ономастичної термінології. Харків, 2012. 256 с. 
нашої розвідки $є$ власні назви, що використовуються в промовах парламентарів на засіданнях законодавчих органів державної влади. Метою статті $є$ дослідження ролі власних назв у політичних промовах парламентарів двох слов'янських країн та двох англомовних країн. Парламент Королівства Великої Британії було створено парламентами Англії та Шотландії після договору про об'єднання у 1707 році. Конгрес США засновано у 1789 році, Національні Збори Польщі існують з 1989 року, а Верховна Рада України - з 1990 року. Ці фактори і стали причиною вибору цих гілок влади у чотирьох країнах для порівняння політичних виступів можновладців. Актуальність теми зумовлена зростанням ролі політичного дискурсу у світі, недостатнім рівнем дослідження використання власних назв у політичних текстах, відсутністю праць 3 компаративістичного вивчення американських, британських, польських та українських політичних промов у ономастичному аспекті. Матеріалом дослідження $є$ тексти промов парламентарів, які представлені на офіційних сайтах Парламенту Сполученого Королівства Великобританії та Північної Ірландії, Конгресу США, Парламенту Республіки Польща (Сенат та Сейм) та Верховної Ради України.

В українській та світовій лінгвістиці політичний текст та політичний дискурс уже давно $є$ сферою інтересів багатьох дослідників (Р. Водак, Т. ван Дейк, Т. Ковалевська, Н. Кондратенко, Г. Почепцов, Л. Славова, Л. Стрій, О. Феофанов, та ін.). Власні назви як складники політичних текстів вивчаються в рамках політичної ономастики. При цьому головними постають питання про те, які інтенції політика знаходять відбиття в імені, як він використовує їх та як аудиторія інтерпретує такі включення у текст. Нині в ономастиці власні назви у політичних текстах досліджено у М. Воєводкіна, М. Рослицької, Ж. Таубаєва, P. Bacot, Margareta Manu Magda тощо. Політична риторика має національні особливості, для різних культур виявляються більш уживаними ті чи інші розряди власних назв. Ступінь насиченості окремого політичного виступу власними назвами може варіюватися. У досліджених виступах парламентарів було знайдено майже всі розряди власних назв, однак домінують антропоніми та топоніми.

\section{1. Соціопрагматичний потенціал антропонімів}

У «Словнику української ономастичної термінології» Д. Бучка та Н. Ткачової власна назва (онім) визначається як «назва, що дається конкретному об'єкту, особі, для виділення його (iі) з ряду однакових чи 
подібних» ${ }^{2}$. Аналізуючи політичні виступи, ми звертали увагу на риторичні та прагматичні властивості власних назв. На використання певних антропонімів впливає мета політичного виступу, жанр, місце виголошення промови, політична ситуація у світі та певній країні, не останню роль відіграє особа оратора. Антропоніми є невід'ємним елементом політичного виступу, крім того, вони мають значний соціокультурний потенціал. У «Словнику української ономастичної термінології» антропонім визначений як «вид онімів, будь-яка власна назва людини (чи групи людей), в т.ч. ім'я, по батькові, прізвище, прізвисько, псевдонім, криптонім, кличка, андронім, гінеконім, патронім» ${ }^{3}$. Антропоніми належать до такого лексичного зрізу, який тісно пов'язаний $з$ життям людини, історією суспільства, культурою народу, тому низка дослідників закріплюють центральне місце в онімному просторі за антропонімами ${ }^{4}$. Серед антропонімів у політичних виступах британських та польських парламентарів трапляються дво- і більше членні антропонімічні формули, наприклад:

My Lords, I refer the House to my relevant registered interests. It is important that everyone living in the United Kingdom learns to speak, read and write English. I endorse the comments of the noble Baroness, Lady Verma, and my noble friend Lady Massey of Darwen. But can the Minister say something about the importance of preserving our other native languages here in the UK - Welsh, Irish, Ulster Scots, Gaelic, Scots and Cornish? (Lord Kennedy of Southwark, 27.07.2020).

Серед антропонімів у політичних виступах американських та українських парламентарів трапляються як одно-, так і більше членні антропонімічні формули, депутати можуть звертатись один до одного по імені або називати когось по прізвищу, наприклад:

Можливо, у Арсена є нова інформаиія (С.М. Шаталова, 11.12. 2020).

Серед виступів українських політиків трапляються як імена, так і прізвища, наприклад:

Середній темп читання дорослої людини - 120-160 слів за хвилину. Ну, ие не Милованов, у нього, звичайно, менше, він сказав на всю крайну, що він дебіл, я не про нього. В інших людей, які здорові, такий темп (Депутат О.О. Гончаренко, 16.01.2020).

2 Бучко Д.Г., Ткачова Н.В. Словник української ономастичної термінології. Харків, 2012. 256 с.

3 Там само.

${ }^{4}$ Jonasson K. Le nom propre. Constructions et interpretations. Louvain-la-Neuve, 1994. $255 \mathrm{p}$. 
Антропоніми, утворюючи ядерну частину онімного простору політичного виступу, інколи несуть смислове та емоційне навантаження, наприклад:

We must act on behalf of people like Azima, a social worker in my home state of Florida who struggles to make monthly copayments for her prescription drugs, which cost more than her rent, electricity, cell phone bill, and car payment combined (Madam Chairwoman Frederica Wilson, 25.07.2019).

Відзначимо, що найчастіше у досліджуваному матеріалі траплялись двочленні та тричленні антропонімічні формули, наприклад:

I знов в нас немає ані пані Тимошенко, ані пані Королевської. Тому, Юліє Миколаӥвно, Вам за всіх презентувати законопроєкт (Депутат М.Б. Радуцький, 11.12.2020).

Політична риторика має певні відмінності, кількість і якість риторичних фігур теж різна. Загалом у колі політиків усього світу найбільшим попитом користуються риторичні фігури, що грунтуються на різного роду повторах, серед яких найбільш затребуваними $\epsilon$ анафора й паралелізм. Крім того, одним 3 ефективних прийомів у політичних виступах, що включає власні назви, можна назвати звертання - слово чи словосполучення у формі кличного відмінка, яке називає особу, до якої звернена мова, наприклад:

Пані Красносільська, я даю вам вказівку придбати майно ...Пане Разумков, я вам раджу придбати майно. Пане Стефанчук, я вам раджу придбати майно. Я вимагаю, даю вам вказівку придбати майно. Ми бачимо, що такі вказівки в тлумаченні Генеральної прокуратури (Депутат С.В. Власенко, 31.10.2019).

Аналізуючи політичні виступи, ми переконалися у частому вживанні повторів антропонімів для посилення емоційного враження від промови, наприклад:

Nie myślcie, że aluzjami o stanie wyjątkowym uda wam się powstrzymać protesty. Wezwanie, które przed kilkoma godzinami zostało wygłoszone przez Jarosława Kaczyńskiego, to skrajnie nieodpowiedzialne zaostrzanie sytuacji. Jak inaczej zrozumieć wystapienie wicepremiera do spraw bezpieczeństwa Jarosława Kaczyńskiego? Czy to jest ogłoszenie PiSowskiego stanu wojennego? Czemu ma służyć to wzywanie członków PiS-u do wyjścia na ulice? Czy Jarosław Kaczyński naprawdę chce doprowadzić do starcia członków PiS z osobami, które protestują? Czy chce rozlewu krwi? (Poseł Kamila Gasiuk-Pihowicz, 27.10.2020).

У політичних виступах найвиразнішими функціями антропонімів є експресивна, що виявляється у тропах - словах, ужитих у переносному значенні. Антропоніми можуть виступати в ролі метонімії - тропа, «що грунтується на вживанні замість імені предмета 
чи явища назви іншого предмета чи явища за суміжністю (тісним зв'язком)» ${ }^{5}$ та метафори - тропа, «який грунтується на прихованому порівнянні одного предмета чи явища 3 іншим на основі перенесення ознаки за принципом подібності чи контрасту» ${ }^{6}$. Загальні риси метонімії та метафори були визначені ще в античній риториці.

Так, у наступному прикладі у виступі польського депутата прізвище Antonov виступає у ролі метонімії та вживається у значенні літак, а саме означає літак Ан-225 «Мрія», що $є$ найбільшим та найпотужнішим у світі транспортним літаком, створеним київським КБ імені Антонова.

Pani Marszałek! Wysoka Izbo! Panie Ministrze! Skuteczna walka z pandemia będzie zależała od skutecznej strategii. Rząd postawił na strategie gigantomanii, pewnych pokazowych akcji. Wiosna to byt gigantyczny Antonov z maseczkami, które okazaty się nieprzydatne, a dziś czytamy artykut $i$ być może rzad będzie musiat się za to wstydzić (Poseł Cezary Grabarczyk, 22.10.2020).

Прагнучі досягти ефекту експресивності, політики послуговуються всім різноманіттям троп. У відомій науковій праці Дж. Лакоффа та М. Джонсона «Метафори, якими ми живемо» автори доводять, що метафора лежить в основі людського мислення й повсякденного спілкування. Ономастична метафора Obama-era передає іншим словам у наступному прикладі образну експресію, внаслідок чого вибудовується певний підтекст у виступі політика.

In the two-and-a-half years since, the Department of Education has:

- Rescinded an Obama-era guidance that provided recommendations to schools seeking to boost diversity in classrooms and campuses (The Chairman Robert C. "Bobby" Scott, 30.04.2019).

Антропонімікон досліджуваних текстів був умовно поділений на групи: 1) імена сучасних державних і політичних діячів; 2) імена письменників; 3) імена вчених; 4) імена релігійних діячів; 5) імена видатних історичних постатей, наприклад:

Президент Зеленський поставив незадовільну оцінку парламенту. Очевидно, це справедлива очінка монобільшості. Ми чекаємо так само на оцінку і для уряду негативної. I не будьте, як казав Василь Стус, кублом злодїв, гвалтівників, які, як партія більшовиків, засіли сьогодні в парламенті. Думаємо про народ (Депутат Т.І. Батенко, 20.10.20).

Наведений приклад є ілюстрацією використання перших двох груп: прізвища Президента України та ім'я та прізвища відомого

5 Макович Х.Я., Вербицька Л.О., Капітан Н.О. Словник термінів і понять 3 риторики. Львів, 2016. 140 с.

6 Макович Х.Я., Вербицька Л.О., Капітан Н.О. Словник термінів і понять з риторики. Львів, 2016. 140 с. 
українського поета, перекладача, прозаїка, Героя України. Антропоніми у виступах депутатів, як у вищезгаданому уривку, ім'я українського поета Василя Cmyca можна віднести до онімів-символів, які не тільки привертають увагу читачів, а й підкреслюють ідею виступу. Фонові знання активізують широкий асоціативний ряд, пов'язаний з іменем Василя Стуса, через що реципієнт повідомлення сприймає багато різних нюансів із політичного виступу.

Зазначимо, що інколи антропонім, який використовується на початку виступу парламентаря, посилює інтерес до змісту. На думку творця бібліопсихології Н. Рубакіна, «слово, що стоїть на самому початку, часто має найближче відношення до слова, що стоїть у самому

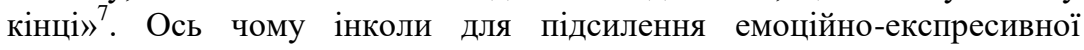
тональності імена політичних діячів вживаються на початку речення, наприклад:

Premiera Morawieckiego nie obchodzi to, że zostawi nas bez emerytur, bez oszczędności na czarna godzinę. Zapewne dlatego pan premier tak goraczkowo zachęca Polaków do samodzielnego oszczędzania na emeryturę (Poseł Magdalena Biejat, 9.01.20).

До третьої групи належать імена вчених. Як показує аналіз матеріалу, ця група антропонімів збільшує ступінь прагматичності виступу, тому вони часто наводяться для підтвердження власного твердження або ідеї парламентаря, наприклад:

Термін «якість дітей» не мій. Хоча за те, щэо я використала його в публічній площииі, я вибачаюсь перед всіма украӥниями $і$ тими, хто сприйняв так, що я якимось чином хочу не захищатати украйнців. Термін не мій. Він згаданий у Гері Стенлі Беккера, це нобелівський лауреат. Ми повинні знати, що світова наука думає, як вирімувати сочіальні питання, і маємо ӥх використовувати (Депутат Г. М. Третьякова, 30.06.2020).

Згадування у виступі британського політика соціологів Сема Фрідмана та Деніеля Лаурісона, авторів книги The Class Ceiling, у якій йдеться про різні можливості для представників різних соціальних класів Британії, виконує також і символічну функцію, бо у своїй книзі автори порушують питання привілеїв у британському суспільстві, наприклад:

Even when disadvantaged students go on to gain a prestigious first, they are still likely to earn around $\$ 7.000$ a year less than more privileged graduates with identical results. The recent State of the Nation report says: "Being born privileged in Britain means that you are likely to remain privileged”. Sam Friedman and Daniel Laurison, authors of The Class Ceiling, go further, describing privilege as a, "following wind ... an energy-

\footnotetext{
${ }^{7}$ Рубакин Н.А. Психология читателя и книги. Москва-Ленинград, 1929. 306 с.
} 
saving device that allows some to get further with less effort" (Baroness Bull, 16.05.2019).

У четверту групу включені імена широко відомих релігійних діячів, а також тих людей, які брали активну участь у християнському житті, наприклад:

I have said before and say again that I did not come into politics to restrict people's liberties, but in the context of Covid I think of the words of the preacher Peter Marshall, who said: "May we think of freedom not as the right to do as we please but as the opportunity to do what is right" (Dehenna Davison, 01.12.20).

Пітер Маршалл - відомий шотландсько-американський проповідник, пастор пресвітеріанської церкви у Вашингтоні, відомий своєю просвітницькою діяльністю, який був призначений капеланом Сенату США. Зазначимо, що депутати часто згадують імена або наводять цитати відомих у своїх країнах політиків, письменників, релігійних діячів тощо 3 метою збільшити експресивність свого виступу, наприклад:

Ви знаєте, колись один з периих батьків иеркви Тертуліан казав: «Вірю, тому ше ие абсурд». Ми віримо в цей законопроєкт, тому щяо він $\epsilon$ абсурдний, друзі (Депутат Т.I. Батенко, 12.12.2019).

Квінт Септимій Флоренс Тертуліан був одним 3 ранньохристіянських теологів, автор сорока трактатів, тому використовується як певний християнський символ. Високий виразовий потенціал мають імена видатних історичних постатей, які ми віднесли до п'ятої групи. У наступному виступі наведена цитата з книги про Вінстона Черчиля.

I am delighted to be called in this debate. By chance, I am currently reading an excellent book on Churchill called "Churchill: Walking with Destiny" by Andrew Roberts, and I am absolutely gripped. Mr. Roberts recounts how listening to the great man's speeches on the radio in occupied countries during the war was punishable by death, "yet still people listened, because he could provide that one thing that these tortured populations needed more than anything else: hope" - hope, optimism, courage and a will to stand up and take on the odds (Richard Drax, 01.12.20).

На нашу думку, в семантиці таких антропонімів, як Churchill, сконцентрована також екстралінгвістична інформація. Таких політичних діячів минулого, як видатний державний діяч Великобританії Вінстон Черчиль, знають у всьому світові, і згадування такої історичної постаті допомагає вплинути як на емоційний, так і на інтелектуальний складник адресата. Слід зазначити, що антропоніміка політичного виступу є потужним механізмом створення позитивного або негативного враження від згаданої особи, наприклад: 
The already rather notorious 4,000-deaths-a-day graph deployed in terrorem at the weekend reminded me of a different claim about a different supposed weapon of mass destruction: chemical and biological weapons ready for use within 45 minutes of an order from Saddam Hussein - we all remember that one (Lord Trevethin and Oaksey, 04.11.2020).

Імена всесвітньо відомих філософів, політиків та інших історичних осіб у позитивному або негативному аспекті стають виразниками певних ідей виступу. Власні назви вживані в політичних виступах можуть символізувати певні ідеї, якості, явища, тому що вони тісно пов'язані як з культурою та історією певного народу, так і з культурою та історією світу. Як слушно зауважує представник Одеської ономастичної школи О. Карпенко, «образність, символізація легше розвивається на базі тих онімів, які ліпше знаєш: тут суб'єктивна вагомість істотніша за вагомість об'єктивну». .

У наведеному нижче прикладі використані два антропоніми, перший з яких - це ім'я короля польського Jan III Sobieski (1629-1696), якого вважають національним героєм Польщі, другий антропонім - це ім'я давньоримського державного діяча Gajusza Juliusza Cezara. Такі антропоніми, як Jan III Sobieski та Gajusza Juliusza Cezara, наділені багатими конотаціями i закріплення знаковості за їх семантикою перетворює їх на оніми-символи.

Bitwa o Warszawe przypomina bardzo bitwe o Wiedeń. Tam Europie zagrażali Turcy, tutaj bolszewicy. I tam, i tu zwycięzcami sa Polacy. Czy tylko? Polski król Jan III Sobieski, pokonawszy Turków, nie przypisat zwycięstwa sobie. Powszechnie znana jest jego parafraza stów Gajusza Juliusza Cezara: Veni, vidi, vici. Po zwycięstwie wiedeńskim nasz król napisze $w$ liście do papieża Innocentego: Venimus, vidimus, Deus vicit przybyliśmy, zobaczyliśmy, Bóg zwyciężyt (Poseł Dariusz Bąk, 20.12.2019).

Використання цитат у політичному виступі не тільки привертає увагу, виражає емоційну напругу, але відсилає адресата до першоджерела. Як стверджував німецький мовознавець і засновник сучасного європейського неогумбольдтіанства Й.Л. Вайсгербер, «з праць минулого лише те досягає нашого часу, що закладено в мові, і навпаки, коли ми, сучасники, вростаємо в нашу рідну мову, то перед нами розкривається досвід довгих тисячоліть» ${ }^{9}$.

8 Карпенко О.Ю. Пряме й образне осмислення онімів у асоціативному експерименті. Наукові записки Тернопільского державного університету. Серія:Мовознавство. № 1(13). 2005. С. 68-80.

${ }^{9}$ Вайсгербер Й.Л. Родной язык и формирование духа. Москва, 2009. 232 с. 
У перебігу дослідження зафіксовано уживання цитат, переказів популярних висловів, які допомагають політику змістовно організувати текстовий простір свого виступу, наприклад:

Where will he find the money for health, welfare and social care, and for the job creation initiatives that will be needed? To paraphrase Tacitus, we will have created a desert and called it protecting the health service (Лорд Forsyth of Drumlean, 4.11.2020).

Тацит Публій (Гай) Корнелій - це римський історик, політичний та державний діяч Римської імперії, відомий своїми трактатами «Аннали», «Германія». У наведеному прикладу антропонім Tacitus виконує як культурно-історичну, так і текстотвірну функції. На нашу думку, успішність комунікації у виступах парламентарів буде залежати не тільки від адресата та підготовленого виступу, а й від фонових знань адресанта. Ще Аристотель у своїй «Риториці», проаналізувавши принципи ораторського мистецтва, звернув увагу на те, що є три види способів переконання: «одні 3 них знаходяться в залежності від характеру мовця, інші - від того чи іншого настрою слухача, треті - від самої промови» ${ }^{10}$.

Отже, однією $з$ властивостей політичних виступів парламентарів $\epsilon$ насиченість власними назвами. Аналіз функціонування антропонімів у політичних виступах парламентарів показав, що правильний добір антропонімів у політичних промовах депутатів досліджуваних країн $\epsilon$ запорукою створення максимально інформативного та експресивного тексту.

\section{2. Культурний потенціал топонімів}

Другою великою групою власних назв у політичних виступах $\epsilon$ топоніми, що відіграють важливу роль у структурно-семантичній організації політичного виступу. Топонім, згідно зі «Словником української ономастичної термінології», - це «вид онімів, власна назва природного або створеного людиною об'єкта на Землі» ${ }^{11}$. У політичному дискурсі топоніми мають конкретну мету застосування: виділяти найважливіші змістові елементи промови, сприяти мобілізації уваги, посилювати емоційний вплив. Засновник Одеської ономастичної школи Ю. Карпенко вважав, що «топонім не так передає географічну чи історичну інформацію, скільки створює образ, лаконічно

${ }^{10}$ Аристотель. Сочинения в 4 т. Т. 2. Москва, 1978. 687 с.

11 Бучко Д.Г., Ткачова Н.В. Словник української ономастичної термінології. Харків, 2012. 256 с. 
висловлюючи цілий комплекс пов'язаних 3 відповідною реалією уявлень і понять, утримує у собі високу емоційну напругу» ${ }^{12}$.

Як було зазначено вище, привернення уваги до політичної промови залежить багато в чому від включення топонімів. Серед топонімів уживаних у політичних виступах було виділено такі розряди: 1) хороніми - «вид топоніма, власна назва будь-якої адміністративнотериторіальної одиниці, яка має визначені кордони» ${ }^{13}$; 2) ойконіми «вид топоніма, власна назва будь-якого поселення: міста, села, а також назви хуторів, висілків і под.» ${ }^{14}$; 3 ) урбаноніми - «вид топоніма, власна назва будь-якого внутріміського об'єкта: вулиці, площі, парку, скверу, окремого будинку (театру, церкви, будинку культури), стадіону, кладовища та ін.» ${ }^{15}$. Центральне місце серед топонімів у політичних текстах займають хороніми, наприклад:

Тому, колеги, я би хотів поговорити про мораль, але не бачу з ким, і це, мені здається, розуміс навіть південь одещини (Депутат Б. В. Яременко, 31.10.2019).

Активне використання топонімів у політичних виступах парламентарів спрямоване не тільки на передачу інформації, але, крім того, ці оніми виконують роль прихованих символів, наприклад:

Mówicie o konwalidacji. Zakładam, że większość z was nawet nie wie, co to słowo znaczy. To słowo znaczy: uzdrowić. Uzdrowić trzeba będzie po was Polskę (Poseł Konrad Frysztak, 27.11.20).

Депутати, як правило, у своїх виступах вживають назви своїх країн, наприклад:

My Lords, does the Minister agree that English is key to helping communities to integrate in Britain and that the importance of learning English should be further emphasised as a precondition to granting British citizenship? (Lord Popat, 27.07.20).

Ойконіми, які трапляються у політичних промовах, виконують роль територіальних чи національних орієнтирів для адресата, наприклад:

I have highlighted in this Chamber on many occasions the impact that coronavirus is having on businesses and residents in Burnley, Padiham, Hapton, Worsthorne and all our other villages (Antony Higginbotham, 01.12.20).

Значна кількість назв міст та сіл трапляється у промовах політиків усіх країн, коли йдеться про поширення коронавірусної хвороби.

12 Карпенко Ю.О. Символічна функція власних назв у поезіях Т. Шевченка. Літературна ономастика : збірник статей. 2008. С. 37-39.

13 Бучко Д.Г., Ткачова Н.В. Словник української ономастичної термінології. Харків, 2012. $256 \mathrm{c}$.

${ }^{14}$ Там само.

15 Там само. 
Топоніми використовується як емоційний вигук з метою привернути увагу адресата до певного регіону у своїй державі, емоційно визначитися зі ставленням адресанта до неї.

Наприклад, така ситуація була в Рівному. Жодного випадку переривання процесу лікування ніде у нас не зафіксовано $і$ зафіксовано не буде, як би ие не маніпулювали і не розповідали наші, скажімо так, і опонентами назвати не можу - так, не зрозуміло (С.М. Шаталова, 11.12.2020).

Для українських депутатів, крім коронавірусної пандемії, ще $\epsilon$ проблема міст країни, які знаходяться у прифронтовому регіоні.

Діти не будують планів в тому, щзо вони поїдуть навчатися десь хоча б до Харкова, до Києва. Діти своє життя будують у своєму невеличкому радіусі. Тобто ие Лисичанськ, Сєвєродонецьк (Депутат О. В. Коваль, 18.11.2020).

У політичних промовах часто трапляються повтори всіх розрядів топонімів. Повторами насичені всі аналізовані промови, оскільки вони здатні упорядкувати, ритмізувати текст, зробити його легшим для сприйняття, наприклад:

In the 1980s, when I was growing up in the west of Scotland, there were very high levels of youth unemployment. In Glasgow, it stood at 80\%. There were few opportunities and little hope. Now, we are walking into something similar. In the 1980s, when I was growing up in the west of Scotland, there were very high levels of youth unemployment. In Glasgow, it stood at $80 \%$. There were few opportunities and little hope. Now, we are walking into something similar (Baroness Clark of Kilwinning, 15.10.20).

Прагнення політиків до стислості та образності своїх виступів спонукає активно вживати тропи. У мовотворчості політиків топоніми як приклади метонімії слугують ефективним засобом увиразнення контексту, наприклад:

Парламент перетворили на нотаріальну контору, яка штампує будь-що, що приходить з Банкової та з Грушевського (Депутат О. О. Гончаренко, 12.11.2019).

У наведеному прикладі вулиця Банкова (урбанонім) вживається на позначення Офісу Президента України, оскільки будівля Офісу розташована саме на цій на вулиці. Аналогічно відбувається метонімічне перенесення вулиці Грушевського (урбанонім) на Кабінет Міністрів України. Для розуміння такої інформації необхідні фонові знання, які відображають зв'язок мови, культури, історії, традиції. У наступному прикладі хоронім California та ойконім New York виступають також у ролі метонімії.

If California and New York can override the FDA on vaccines, what would prevent Republican Governors from banning $R U-486$, the abortion 
drug, in their States? If that were to happen, I am sure my Democratic colleagues would cry politics and suggest that if FDA has reviewed and approved a drug and said it is safe and effective, then, States should not be able to say that it is unsafe (Senator Sherrod Brown, 24.10.20).

$\mathrm{y}$ політичних промовах фігурують ономастичні метонімії та метафори, оскільки допомагають впливати на адресат своєю виразністю та слугують засобом семантичної економії мови. Метонімічні топоніми не лише виконують номінативну функцію, а й виконують підсилювальну ідеологічну функцію, наприклад:

Today, it appears that Azerbaijan and Turkey are determined to make good on their threats. With bombs, and drones, and Syrian mercenaries, Turkey and Azerbaijan are pushing ahead with a war that has no end in sight. The Armenian people are the grandchildren and great-grandchildren of the genocide perpetrated a century ago by the Ottoman Empire, and the words and deeds of Erdogan and Aliyev today call to mind the crimes of one hundred years ago. We cannot allow history to repeat itself. If Azerbaijan and Turkey have determined to wage war, the United States, the Minsk Group, and the International Community should make clear that they will not succeed in their aims (Hon. Adam B. Schiff, 23.10.20).

Прагматична значущість хоронімів Azerbaijan та Turkey допомагає будувати асоціативне поле. Метонімічні хороніми замінили багатокомпонентну структуру політичне керівництво Азербайджанської Республіки та Турецької Республіки.

Під час дослідження ми звернули увагу на роль персоніфікації у політичних виступах. Персоніфікація $\epsilon$ різновидом метафори, що «Грунтується на перенесенні ознак з особи на предмет або явище, коли неживе виконує дію живого (діє, як людина), олюднюється, одухотворяється» ${ }^{16}$, наприклад:

...я розумію, щя в нас Мінфін вважає, щчо Украйна першою в світі переможе ковід, тому нам гроші після березня на боротьбу з ковідом не потрібні. Так, у нас там стоять нулі, в нас не вистачає грошей на підняття зарплат (Депутат М. Б. Радуцький, 11.12.2020).

У наведеному нижче прикладі, присвяченому трагедії вбивства афроамериканця Джорджа Флойда, яке спричинило хвилю протестів у США у 2020 році, політичний оратор емоціоналізує свій виступ за допомогою персоніфікації та повторів хороніма America. Синтаксичний паралелізм - розташування в кількох фразах слів в ідентичному порядку - дозволяє зробити елемент тексту максимально виразним,

16 Макович Х.Я., Вербицька Л.О., Капітан Н.О. Словник термінів і понять з риторики. Львів, 2016. 140 с. 
додати більше глибинного сенсу й емоцій; опис стає повнішим, об'ємним, яскравим.

America is crying and America is weeping... America is crying for help just like George Floyd did (Mr. Richmond, 25.06.2020).

Висока частотність прикладів персоніфікації у текстах парламентарів майже всіх досліджуваних країн вмотивована багатьма чинниками: вони привертають увагу до конкретної події, здійснюють ефективний вплив на аудиторію, створюють запланований фон для сприйняття. У політичному дискурсі часто мають місце оціночні судження, що утворюють антитезу. Антитеза, як правило, використовується для протиставлення правильних дій або якостей неправильним діям або якостям 3 метою вплинути на адресат. Оцінки при цьому відрізняються яскраво вираженою полярністю, будуються на бінарних опозиціях, можуть включати будьяку градуальність, наприклад:

Але, шановні колеги, досвід Грузії ие не паначея. Бо Украйна - не Грузія (Депутат М. М. Цимбалюк, 19.12.2019).

Хороніми Украӥна та Грузія вживаються у наведеному прикладі як засіб компресії інформації. Це один з випадків, коли фігури мовлення виступають як засоби структурної і смислової організації дискурсу, які, будучи своєрідним синтаксичним каркасом тексту, увиразнюють мовленнєві наміри політика.

Для адресата необхідно вміти правильно інтерпретувати виражальні засоби мови. Одним із прийомів у політичних виступах парламентарів $\epsilon$ перифраз, тобто стилістичний прийом заміни існуючої назви предмета описовим зворотом, який називає ознаки неназваного предмета, залежно від індивідуального бачення політика. Відомо, що у промовах ораторів античності перифраза виконувала функцію уникнення прямого називання небажаних явищ, що надавало думкам, які висловлював ритор, більшої привабливості й переконливості.

Французький лінгвіст Ш. Баллі наголошував: «Мова служить потребам комунікації, яка дає змогу передавати думку з максимальною точністю і мінімальною витратою зусиль тим, хто говорить, і тим, хто слухає» ${ }^{17}$. Політик прагне мови образної та емоційної. Ономастичні перифрази, крім номінативної, виконують культурно-історичну, експресивну та текстотвірну функції та розкривають світосприйняття політика. Так, у виступі британського парламентаря вживається ономастичний перифраз Carey Street для того, щоб не називати до чого призведе коронавірусний локдаун для британців, а саме до банкрутства.

The Chancellor has done brilliantly, but he knows we are heading for Carey Street. What will this lockdown cost - perhaps £12.5 billion for

\footnotetext{
${ }^{17}$ Балли Ш. Французская стилистика. Москва, 1961. 394 с.
} 
furlough and the self-employed alone? He will need to extend the $£ 20$ a week standard allowance for universal credit from April (Lord Forsyth of Drumlean, 04.11.2020).

За певними топонімами ми бачимо широке смислове поле. Фраза оn Carey Street походить 3 Лондонської вулиці, де раніше знаходився суд з питань банкрутства Великобританії.

Отже, застосування топонімів у політичних виступах сприяє конденсації інформації, увиразнює мовлення, формує запланований політиком фон виступу. Кожен 3 розрядів топонімів має власне змістове навантаження та впливає на структуру політичного виступу, але найбільш поширеними в аналізованих виступах $є$ хороніми, ойконіми та урбаноніми.

\section{ВИСНОВКИ}

Отже, політичні виступи парламентарів $є$ продуктом політичної комунікації. Політичні виступи парламентарів Парламенту Сполученого Королівства Великобританії та Північної Ірландії, Конгресу США, Парламенту Республіки Польща (Національні Збори Польщі) та Верховної Ради України мають такі специфічні ознаки, як структурованість, цілісність, символічність, культурну детермінованість. У всіх країнах політичні виступи парламентарів $\epsilon$ віддзеркаленням подій, що відбуваються у країнах.

Система національної ідентичності будь-якого народу складалася протягом тривалого часу. Власні назви $є$ частиною цієї системи $\mathrm{i}$ являють собою когнітивний конгломерат, в якому відображені культура і релігія, література та історія. У будь-якій національній культурі існують властиві тільки ій символи, дати й імена, які відображають знакові історичні події, національних героїв, географічні об'єкти, назви книг і свята колишніх епох і сучасності. Ось чому власна назва $є$ невід'ємним елементом політичного виступу. Навколо майже кожної власної назви може утворюватися цілий ореол всіляких асоціацій, часом спонтанних i неусвідомлених, тому в промовах парламентарів власні назви сприяють приверненню уваги, урізноманітненню викладу, допомагають виділити основну ідею та емоціоналізувати виступ.

Політична риторика парламентарів різних країн має певні відмінності, кількість і ступінь частоти власних назв у виступах теж різна, але особливе місце відводимо антропонімам та топонімам через їхній експресивний потенціал. $\mathrm{y}$ мовотворчості сучасних парламентарів $\epsilon$ багато прикладів ономастичних метафор, метонімій, повторів, які не тільки увиразнюють політичний виступ, а й сприяють вираженню позитивної чи негативної оцінки. Потужне експресивне 
забарвлення мають ономастичні перифрази, які $є$ важливою ознакою образності політичної мови. Важливим показником, який свідчить про прагматичність політичних виступів, $\epsilon$ використання онімів-символів.

Отже, 3 аналізованих досліджень виступів членів Парламенту Сполученого Королівства Великобританії та Північної Ірландії, Конгресу США, Парламенту Республіки Польща (Національні Збори Польщі) та Верховної Ради України висновуємо, що власні назви ефективний інструментарій для створення політичних текстів 3 ущільненою інформативністю. Вивчення політичних текстів з точки зору ономастичного підходу допомагає аналізувати соціум країн у певний період часу.

\section{АНОТАЦІЯ}

Вплив слів політичних діячів на думки людей завжди визнавався вченими і піддавався всебічному аналізу в психології, соціології та мовознавстві. У наш час, коли роль політики у світі зростає, конкуренція між політичними діячами загострюється, аналіз змісту політичних виступів стає все більш важливим. Ефективність політичного виступу досягається використанням різних виразних засобів мови, зокрема, тропів і фігур мови (наприклад, метонімія, повторення тощо), акцентуванням уваги на найбільш значущих елементах висловлювання (наприклад, власні назви). Однією 3 найбільш помітних особливостей сучасних політичних текстів $\epsilon$ велика кількість власних назв. Ось чому вивчення ономастичних елементів у сучасних політичних текстах має особливе значення. Метою дослідження $є$ аналіз власних назв, що використовуються в політичних текстах представниками парламентів у різних мовних культурах. Дослідження політичних текстів у суміжних та неспоріднених мовах дозволило встановити відмінності та загальні риси онімної організації політичних виступів.

\section{ЛITЕРАТУРА}

1. Аристотель. Сочинения в 4 т. Т. 2. Москва, 1978. 687 с.

2. Балли Ш. Французская стилистика. Москва, 1961. 394 с.

3. Бучко Д.Г., Ткачова Н.В. Словник української ономастичної термінології. Харків, 2012. 256 с.

4. Вайсгербер Й.Л. Родной язык и формирование духа. Москва, 2009. 232 c.

5. Карпенко О.Ю. Пряме й образне осмислення онімів у асоціативному експерименті. Наукові записки Тернопільского державного університету. Серія: Мовознавство. № 1(13). 2005. C. $68-80$. 
6. Карпенко Ю.О. Символічна функція власних назв у поезіях Т. Шевченка. Літературна ономастика : збірник статей. 2008. C. 37-39.

7. Макович Х.Я., Вербицька Л.О., Капітан Н.О. Словник термінів і понять з риторики. Львів, 2016. 140 с.

8. Рослицька М.В. Прецедентне ім'я в політичному дискурсі: формально-семантичні ознаки $\mathrm{i}$ соціопрагматичний потенціал (на матеріалі промов президентів України, Польщі та Франції кін. XX поч. XXI ст.) : дис. ... канд. філол. наук : 10.02. 15. Львів, 2019. 357 с.

9. Рубакин Н.А. Психология читателя и книги. Москва-Ленинград, 1929. $306 \mathrm{c}$.

10. Jonasson K. Le nom propre. Constructions et interpretations. Louvain-la-Neuve, 1994. 255 p.

Information about the author:

Nasakina S. V.,

Candidate of Philological Sciences, the Head of the Ukrainian and Foreign Languages Department, Odesa State Agrarian University 13, Panteleymonivska str., Odesa, 65012, Ukraine 